\title{
THE EFFECT OF DIFFERENT ACID TREATMENTS ON SHEAR BOND STRENGTH BETWEEN MONOLITHIC ZIRCONIA AND DENTIN SURFACE
}

\begin{abstract}
Objective: The aim of this study is to evaluate the effect of dentin surface treatments with citric, tartaric, phosphoric, and boric acids on the bonding strength of monolithic zirconia.
\end{abstract}

Materials and Methods: A hundred human molar teeth were randomly divided into subsets $(n=10)$ based on acid treatment modalities and thermocycling procedure. Monolithic zirconia superstructures were fabricated using CAD/CAM system in the final dimensions of $7 \mathrm{~mm}$ in diameter and $3 \mathrm{~mm}$ in thickness. After application of acid treatments to dentin surface, shear bond strength test was performed to assess the effectiveness of surface modifications that were also examined using a scanning electron microscope.

Results: The study groups were ranked respectively as (citric acid>tartaric acid>phosphoric acid>boric acid>control) for the set of groups without thermocycling and (citric acid $>$ tartaric acid) and (phosphoric acid>boric acid>control) for the set of thermocycling groups $(\mathrm{p}<0.05)$ based on highest value. The bonding strength of tartaric acid group was not significantly different from the bonding strength of phosphoric acid group ( $p>0.05$ ).

Conclusions: In both procedures with and without thermal cycling; based on order of efficacy, citric, tartaric, phosphoric, and boric acids were more effective in improving the shear bond strength between monolithic zirconia and dentin surface. The thermal cycling procedure decreased the bonding strength in all the groups.

Keywords: Boric acid, citric acid, phosphoric acids, zirconium oxide, dentin, shear strength.
*Melih Ulgey ${ }^{1}$

Oguzhan Gorler ${ }^{1}$

ORCID IDs of the authors:

M.U. 0000-0001-5859-7071

O.G. 0000-0001-6545-8811
Received : 02.10 .2020

Accepted : :11.12.2020

How to Cite: Ulgey M, Gorler O. The Effect of Different Acid Treatments on Shear Bond Strength Between Monolithic Zirconia and Dentin Surface. Cumhuriyet Dent J 2021;24:1:1-9.

* Corresponding Author:

Department of Prosthodontics, Faculty of Dentistry, Sivas Cumhuriyet University, Sivas, Turkey.

E-mail: melihulgey@gmail.com 


\section{INTRODUCTION}

Zirconia is preferred by clinicians over recent years in dentistry. As a result of the introduction of computer-aided design and computer aided manufacturing (CAD/CAM) technology to dental laboratories and clinics, the use of zirconia material for the production of prosthesis has rapidly increased. ${ }^{1}$ This material provides good success in prosthetic rehabilitation because of its advantages including biocompatibility, high fracture toughness, and esthetic properties. ${ }^{2,3}$ Thus, the use of zirconia material has led to high mechanical strength and good esthetic outcome for patients. Veneering of zirconia frameworks is a conventional method used by the dental technicians. $^{4}$ With this technique, veneered zirconia provides natural appearing because of its white color but chipping or delamination of the feldspathic porcelain layer over the zirconia framework is the most common complication of this restoration. ${ }^{5}$ Therefore, full-contour zirconia has been presented as an alternative to conventionally veneered zirconia.

Monolithic zirconia enables to produce high strength prosthesis with reasonable esthetic results, time and cost as a new alternative dental prosthetic treatment. In addition, due to the use of anatomic contour zirconia, major complication of conventionally veneered zirconia has been eliminated. ${ }^{6}$ Monolithic zirconia restorations have a higher fracture strength when compared to the maximal occlusal forces (383.6 in women - 545.7 $\mathrm{N}$ in men) in the posterior location of the mouth., For the long-term success of monolithic zirconia restoration in posterior region of the mouth, minimum occlusal thickness should be $0.7 \mathrm{~mm}$ for implant-supported restorations and $0.5 \mathrm{~mm}$ for tooth-supported restorations to endure the chewing forces. ${ }^{2,9}$ This is an important advantage in the clinical situations including limited interarch distance, the need for preservation of tooth structure, and inadequate clinical crown length. ${ }^{10}$

Sufficient bonding strength between zirconia material and dentin surface is an important matter for successful functioning of a ceramic restoration. ${ }^{11}$ For the luting of zirconia restorations, resin cements are preferred for their advantageous mechanical and adhesive features compared to conventional cements. Providing a strong bonding with resin cement depends on chemical type of bonding and micromechanical retention to the material surface. ${ }^{12}$ In the literature, researchers have aimed to improve retention of zirconia crowns with the surface treatment of zirconia with grinding, sandblasting, airborne-particle abrasion, acid and laser etching, silanization, or a combination of these methods. ${ }^{3-15}$ On the other hand, modification of dentin surfaces may improve the bonding strength of zirconina ceramics. ${ }^{16}$ Data about the efficacy of acid treatments in terms of improving the bonding strength between dentin surface and zirconia are limited.

Retention of monolithic zirconia to abutment teeth should be adequate to withstand the masticatory forces especially in the case of reduced clinical crown length. ${ }^{17}$ However, there is still no consensus on the improving bonding strength between monolithic zirconia and dentin surface if there is a reduced clinical crown length. The aim of this study was to evaluate the effect of dentin treatments with citric, tartaric, phosphoric and boric acids on the bonding strength of monolithic zirconia. The null hypothesis was that the shear bond strength of the monolithic zirconia that was bonded to dentin surface after surface modifications with citric, tartaric, phosphoric and boric acids would not be altered by acid etching process.

\section{MATERIAL AND METHODS}

The study was approved by the Committee on Human Research of (No: 2016-12/11). A hundred human permanent mandibular molar teeth extracted due to clinical reasons were used in this study. Teeth were free of restoration, caries, and cracks. After having been scraped of any residual tissue tags, they were kept at $+4^{\circ} \mathrm{C}$ in $0.9 \%$ saline solution during the whole study. Occlusal enamel of each molar tooth was separated into the crowns parallel to the occlusal surface and middle-dentin surface was exposed with a precision low-speed diamond saw (Isomet 1000, Buehler, Lake Buff, IL, USA). The part of the teeth including the roots was fixed with autopolymerizing acrylic resin (Meliodent, Heraeus Kulzer, Wehrheim, Germany) to form $2.5 \mathrm{~cm}$ high 
and $1.5 \mathrm{~cm}$ diameter cylinders. Roughness of dentin surfaces was standardized with $600-800$ and 1200 grit waterproof polishing papers.

Monolithic zirconia (Katana, Noritake Dental Supply Co. Ltd., Aichi, Japan) superstructures were fabricated using CAD/CAM system (DC40, Yenadent, Ankara, Turkey) in the final dimensions of $7 \mathrm{~mm}$ in diameter and $3 \mathrm{~mm}$ in thickness in accordance with the ISO 11405 standard. The specimens were sintered to full density in a hightemperature furnace (Protherm; B\&D Dental Origin Milling, USA) according to the manufacturer's instructions.

In this study, we determined the optimal concentration and application time of acid agents with a pilot study because of limited information in the literature. For each acid surface treatment modality, 3 acid concentrations $(5 \%, 10 \%, 15 \%)$ were applied to dentin surface at 5 application times $(5,10,15,20,25$ s). For every acid agent, 3 pilot groups were selected according to stereomicroscope evaluation of pore structures. In order to determine the optimal concentration and application time, shear bond strength test was performed using universal test device (LF Plus, Lloyd Instruments, Fareham, England) in selected 3 pilot groups. Thus, for every acid surface treatment modality, the optimal concentration and application time were determined after statistical analysis of the data obtained from the pilot groups (Table 1).

Table 1. Concentration and application time of acid treatments.

\begin{tabular}{lcc}
\hline Groups & Concentration $(\%)$ & Application Time $(\mathrm{s})$ \\
\hline Boric Acid & 5 & 20 \\
Phosphoric Acid & 32 & 15 \\
Tartaric Acid & 15 & 15 \\
Citric Acid & 10 & 25 \\
\hline
\end{tabular}

The examined teeth were divided into two sets, one of which was subject to thermocycling $(n=50)$. Each set was divided randomly into five subgroups according to acid treatment modality: no treatment (control), boric, phosphoric, tartaric, and citric acids $(n=10)$.

Control Group: No treatment

Boric Acid Group: A 5\% boric acid solution (Multicell; Wisent, Inc., Quebec, Canada) was prepared and applied to dentin surfaces with burnishing movement using a sponge for $20 \mathrm{~s}$. The specimens were rinsed for $20 \mathrm{~s}$ and dried with oilfree compressed air for $10 \mathrm{~s}$.

Phosphoric Acid: Commercially available 32\% phosphoric acid gel (Scotchbond Universal Etchant; 3M ESPE Dental Products, MN, USA) was applied to dentin surface for $15 \mathrm{~s}$. The specimens were rinsed for $20 \mathrm{~s}$ and dried with oilfree compressed air for $10 \mathrm{~s}$.

Tartaric Acid: A 15\% tartaric acid solution (Merck\&Co., Inc., NJ, USA) was applied to dentin surface with burnishing movement using a sponge for $15 \mathrm{~s}$. The specimens were rinsed for $20 \mathrm{~s}$ and dried with oil-free compressed air for $10 \mathrm{~s}$.
Citric Acid: Dentin surfaces were roughened with 10\% citric acid solution (Merck\&Co., Inc., NJ, USA) with burnishing movement using a sponge for $25 \mathrm{~s}$. The specimens were rinsed for $20 \mathrm{~s}$ and dried with oil-free compressed air for $10 \mathrm{~s}$.

After surface modifications, a self-adhesive resin cement (Panavia SA, Kuraray, Osaka, Japan) was used for the cementation of monolithic zirconia crowns to dentin surfaces. Constant hand pressure was applied by one operator to zirconia specimens during the cementation. Excess resin cement was initially removed from the periphery of the zirconia specimen with an explorer and light cured with a LED curing unit (Smartlite, Dentsply, York, USA) for totally $100 \mathrm{~s}$ from 5 different directions. Before the application of shear bond strength test, half of the specimens were stored in the aqueous incubation (Nuve BM 302; Nuve San., Ankara, Turkey) at $37^{\circ} \mathrm{C}$ for 24 hours and the other half was thermocycled (GM, Gokceler Mechanical, Sivas, Turkey) for 3000 cycles in $5^{\circ} \mathrm{C}$ and $55^{\circ} \mathrm{C}$ water baths with a dwell time for $30 \mathrm{~s}$.

The specimens were placed in a universal testing machine (Lloyd LF Plus, Ametek Inc, Lloyd Instruments, Leicester, UK) without drying 
immediately after the specimens were removed from the distilled water and the shear bond strength was performed at a crosshead speed of $1 \mathrm{~mm} / \mathrm{min}$ until failure. The shear force was recorded in Newtons (N) and calculated in MPa by considering the crosssectional area of the monolithic zirconia. The mean and standard deviation were calculated for different groups. The specimens were evaluated using a scanning electron microscope (SEM) (Tescan Mira 3, Brno, Czech Republic) at x5000 magnification after shear bond test to examine how the zirconia specimen detached and how acid treatments produced irregularity on the dentin surface.

\section{Statistical Analysis}

The data of shear bond strength were analyzed with two-way ANOVA followed by the Tukey test for pairwise comparisons. Data are presented as the mean plus or minus standard deviation (SD). Differences were considered significant at level of 0.05 .

\section{RESULTS}

Table 1 shows the optimal concentration and application time for every acid surface treatment modality which determined after statistical analysis of the data obtained from the pilot groups.

Figure 1 shows the values of shear bond strength between monolithic zirconia and dentin surface treated with boric, phosphoric, tartaric, and citric acids.



Figure 1. Figure 1. Values of shear bond strength between monolithic zirconia and dentin surface treated with boric, phosphoric, tartaric and citric acids. Data were expressed as mean (midline) and SD (whiskers). aP $<0.05$, citric acid with thermocycling vs. citric acid without thermocycling. $\mathrm{bP}<0.05$, boric acid with thermocycling vs. boric acid without thermocycling. $\mathrm{cP}<0.05$, phosphoric acid with thermocycling vs. phosphoric acid without thermocycling. $\mathrm{dP}<0.05$, boric acid with thermocycling vs. boric acid without thermocycling. $\mathrm{eP}<0.05$, control group with thermocycling vs. control group without thermocycling. $\mathrm{fP}<0.05$, citric acid vs. other groups with thermocycling. $\mathrm{gP}<0.05$, tartaric acid vs. boric and control groups with thermocycling. $\mathrm{hP}<0.05$, phosphoric acid vs. boric and control groups with thermocycling. iP $<0.05$, boric acid vs. control group with thermocycling. $\mathrm{j} P<0.05$, citric acid vs. other groups without thermocycling. $\mathrm{kP}<0.05$, tartaric acid vs. phosphoric, boric, and control groups without thermocycling. $1 \mathrm{P}<0.05$, phosphoric acid vs. boric and control groups without thermocycling. $\mathrm{mP}<0.05$, boric acid vs. control group without thermocycling.

ANOVA and tests revealed that the bonding strengths of the specimens were significantly different. First, the effect of thermal cycling procedure was compared in all the groups. In all the groups, application of thermocycling procedure provided a significant decrease in the bonding strength between monolithic zirconia and dentin surface $(p<0.05)$. In the set of thermocycling group, the bonding strength was significantly higher in the citric acid than the other groups $(\mathrm{p}<0.05)$. The bonding strength of tartaric acid was significantly higher compared to the boric and control groups $(\mathrm{p}<0.05)$. The phosphoric acid had significantly higher bond strength compared to boric and control groups $(\mathrm{p}<0.05)$. The bonding strength of boric acid was significantly higher than that of control group ( $\mathrm{p}<0.05$ ). Although the bonding strength of tartaric acid was higher than the bonding strength of the phosphoric acid, this difference was not statistically significant ( $p>0.05)$.

In the set of the groups without thermocycling, it was significantly higher in the citric acid than the other groups $(\mathrm{p}<0.05)$. The tartaric acid had significantly higher bonding strength compared to phosphoric, boric and control groups $(\mathrm{p}<0.05)$. The bonding strength of phosphoric acid was significantly higher in the boric and control groups $(\mathrm{p}<0.05)$. The boric acid provided a significant increase in the bonding strength compared to control group $(\mathrm{p}<0.05)$ (Table 2). 
Table 2. Shear bond strength values (MPa) for all samples

\begin{tabular}{lcccc}
\hline Groups & \multicolumn{2}{c}{ No Thermal Cycling } & Thermal Cycling \\
\hline & Mean & Standard deviation & Mean & Standard deviation \\
\cline { 2 - 5 } Control & $2.907^{\mathrm{a}}$ & 0.109 & $2.594^{\mathrm{a}}$ & 0.097 \\
Boric Acid & $4.407^{\mathrm{b}}$ & 0.204 & $3.953^{\mathrm{b}}$ & 0.140 \\
Phosphoric Acid & $4.838^{\mathrm{c}}$ & 0.221 & $4.465^{\mathrm{c}}$ & 0.154 \\
Tartaric Acid & $5.724^{\mathrm{d}}$ & 0.238 & $4.637^{\mathrm{c}}$ & 0.165 \\
Citric Acid & $6.062^{\mathrm{e}}$ & 0.255 & $5.613^{\mathrm{d}}$ & 0.227 \\
\hline
\end{tabular}

Citric Acid

Figures 2 showed the surface morphology of representative dentin after different treatments observed by a SEM.


Figure 2. Scanning electron microscope images of dentin surfaces treated by boric, phosphoric, tartaric, and citric acids.
The SEM images showed that the pore structures with regular and deep edges were observed in the citric acid group (\%10 for $25 \mathrm{~s}$ ). In tartaric acid group ( $15 \%$ for $15 \mathrm{~s})$, the pore diameters were smaller than the pores caused by citric acid. It is observed that the pore structures in the phosphoric acid group (32\% for $15 \mathrm{~s}$ ) had irregular edges than the citric acid and they formed with less frequent intervals. In boric acid group ( $\% 5$ for $20 \mathrm{~s}$ ), it was observed that the pore diameters were highly smaller, shallow and irregularly distributed than the other acids. In all the groups, it was seen that cements filled in the pore cavities after the SBS test.

\section{DISCUSSION}

The results support the rejection of the null hypothesis because all acid treatments significantly increased the bonding strength between monolithic zirconia and dentin surface. This study revealed that (1) thermal cycling procedure decreased the bonding strength in all the groups; (2) application of acid treatments to dentin surface increased bonding strength values; (3) in both procedures with and without thermal cycling; based on order of efficacy, citric, tartaric, phosphoric, and boric acids were more effective in improving the shear bond strength between monolithic zirconia and dentin surface; (4) the most favorable results in bonding strength measurements were obtained with citric acid solution; (5) boric acid provided less success among the acid agents.

Citric acid has been used for many years in root surface treatment applications in periodontology field and in the disinfections of root canals applications in endodontics field. ${ }^{18,19}$ Citric acid is a convenient agent for surface treatments due to its erosive character ${ }^{20}$; however, the number of surface treatment studies in prosthodontics field is limited in the literature. Ravikumar et al. 
evaluated the bonding strength of AH Plus Sealer to root dentin surface treated with EDTA, maleic acid, citric acid and MTAD agent, it was determined that the post-irrigation bonding strength values were not significantly different between citric acid and EDTA groups. ${ }^{21}$ Akisue et $a l$, compared the shear bond strength of four resinbased sealers to dentin treated with citric acid solution or Er:YAG irradiation. They concluded that RealSeal and $15 \%$ citric acid solution achieved the best results regarding the sealer and pretreatment used. ${ }^{22}$ Kameyama et al., evaluated the effect of aqueous solutions of $10 \%$ citric acid (10-0) or $10 \%$ citric acid/3\% ferric chloride (10-3) on resin bonding to dentin following irradiation with an Er:YAG laser. They examined that ferric chloride included in an aqueous solution of $10 \%$ citric acid (10-3) was effective in acid treatment for bonding 4-METAMMA-TBB resin and dentine. They concluded that ferric chloride in citric acid prevented the denaturing of collagen and prevented the collapse of demineralized collagen network. It is also known that collapse of demineralized collagen was similar between $10-3$ and $10-0 .{ }^{23}$ Demiryurek et al., evaluated the effects of different surface treatments on the bond strength of a fiber post to dentin. They calculated that irrigation with $10 \%$ citric acid increased the push-out bonding strength values 4 times than the control group. ${ }^{24}$ In the present study, $10 \%$ citric acid treatment for 25 $\mathrm{s}$ on the dentin surface achieved the highest bonding strength value. This situation can be explained by the formation of regular and smooth pore structures on the dentin surface by the citric acid treatment and the attachment of the resin cement on the pore structure.

Tartaric acid is incorporated into glass ionomer cements in order to control the setting characteristics and provide easy mixing. ${ }^{25}$ The tartaric acid mainly occurs mainly in wine and grapes and this acid is deemed to be extremely erosive to dental hard tissues. ${ }^{26} \mathrm{Fu}$ et al., investigated the interfacial interaction of tartaric acid with hydroxyapatite and enamel. The authors concluded that the enamel etched with tartaric acid mainly revealed decalcification of the periphery of the enamel rods. Etching of enamel tissue for $30 \mathrm{~s}$ may be appropriate for resin-to-enamel bonding via micro-retentive interlocking. Therefore, tartaric acid might be used as an etchant and functional ingredient in self-etching primers. ${ }^{27}$ In the present study, the application of $15 \%$ tartaric acid agent on the dentin surface for $15 \mathrm{~s}$ increased the bonding strength values than the bonding strength values of the control group.

Application of phosphoric acid to dentin surface provides further exposure of dentin tubules and this is beneficial for the penetration of monomer of resin cement. ${ }^{28}$ Juloski et al., assessed the effect of preliminary phosphoric acid-etching on shear bond strength (SBS) to enamel and dentin of a self-adhering restorative composite and of a new self-etch adhesive used in combination with the proprietary flowable composite. The authors concluded that phosphoric acid treatment of the substrate before applying Vertise Flow or OptiBond XTR did not significantly change their adhesion potential to enamel and dentin. In their study, SEM observations showed that phosphoric acid pretreatment did not change the etching pattern of self-etching adhesives but just increased the depth of etching. ${ }^{29}$ Poggio et al., compared the bond strength of different universal adhesives under three testing conditions; when no pretreatment was applied, after $37 \%$ phosphoric acid etching and after glycine application. They suggested that acceptable bond strength values could be obtained with no dentin pretreatment regardless the adhesive system used in reduced sensitivity technique conditions. They also suggested that acid pretreatment should be localized only to enamel. ${ }^{30}$

Alaghehmand et al., determined the microshear bond strength of composite resin on superficial and deep dentin after conditioning with phosphoric acid and Erbium-Doped Yttrium Aluminum Garnet (Er:YAG) laser. They suggested that laser treatment of dentin surfaces negatively affected the bond strength compared to acid etching. The authors noted that this controversy might be partly due to the heterogeneity of methods for dentin conditioning via laser. ${ }^{31}$ Davari et al., investigated the shear bond strength of an etch-andrinse adhesive system to dentin surfaces following 
Er:YAG laser and/or phosphoric acid etching. They concluded that phosphoric acid etching was still an effective dentin pretreatment technique for composite resin restorations ${ }^{32}$ In the present study, application of $32 \%$ phosphoric acid for $15 \mathrm{~s}$ to dentin surface improved the bonding strength of monolithic zirconia specimens but citric and tartaric acids provided more favorable results. This situation may be associated with the fact that citric and tartaric acids more effectively regulated dentin tubules by protecting the hybrid layer on the dentin surface.

Boric acid (BA) is a weak, inorganic acid used in clinical and industrial applications. ${ }^{33}$ In dental field, boric acid is used as cavity disinfectant agent because of bacteriostatic and fungistatic properties. ${ }^{34}$ In the literature, the use of boric acid in "surface treatment" studies is limited. Ercan $e t$ al. evaluated the effect of ozone, chlorhexidine and boric acid on shear bond strength between tooth dentin and composite buildups. They suggested that chlorhexidine and boric acid significantly decreased the strength of the bond, and there was significant difference between the shear bond values. ${ }^{35}$ Although application of 5\% boric acid for $25 \mathrm{~s}$ was increased the bonding strength compared to no treatment group in our study, other acids were more successful in terms of enhancing bonding quaility between zirconia and dentin surfaces. This may be due to less-invasive characteristic of boric acid. This characteristic was also observed in SEM observations which pore diameters were smaller and shallow.

Thermal cycling procedure allows understanding the effect of thermal stresses on bonded interfaces of restorative materials. With this procedure, in vivo process can be simulated in laboratory conditions. ${ }^{36}$ In present study, thermal cycling procedure was negatively effect to the bonding strength of monolithic zirconia specimens cemented to the dentin surface. Mechanical stresses originated from thermal changes may be affect bonding quality in bonding interfaces.

The authors of the present study are aware that the data of the current trial have to be interpreted within its limitations. For modification of the dentin surface, we used phosphoric acid in gel form. It is known that application of solution form of the agent is more effective than gel form. ${ }^{37}$ Nevertheless, the data of the present study should be supported by clinical studies as decreasing in debonding rate of monolithic zirconia crowns can be adequately experienced in oral environment. Further studies maybe helpful to determine the effect of their different concentrations to optimize the potential merit of citric acid for use before the cementation.

In conclusion, the surface treatment by the means of applied acid treatments produces positive changes in the surface morphology of dentin surfaces. The main idea of the present study was to include different acid surface treatments including citric, tartaric, phosphoric and boric acids, and investigation if the bond strength between monolithic zircoina and dentin surface would be affected by different specifications of these acid agents. Current experiments supported that application of citric, tartaric, phosphoric, and boric acids on the dentin surface can increase the shear bond strength between monolithic zirconia and dentin surface. In addition, to the best of the authors' knowledge, there has been no study examining the effect of these acid treatments on the bonding of monolithic zirconia crowns in the same laboratory settings, and the current experiments provided in vitro data about the preferring the appropriate acid treatment for cementation of these crowns.

\section{CONCLUSIONS}

Based on the limitations of present study, the following conclusions may be drawn:

1. Application of acid treatments is effective to increase bonding strength between monolithic zirconia and dentin surface.

2. The thermal cycling procedure decreased the bonding strength in all the groups.

3. In both procedures with and without thermal cycling; based on order of efficacy, citric, tartaric, phosphoric, and boric acids were more effective in improving the shear bond strength between monolithic zirconia and dentin surface. 
4. Treatment with $10 \%$ citric acid of dentin surface for $25 \mathrm{~s}$ is suggested cementation process of monolithic zirconia restorations.

\section{ACKNOWLEDGEMENTS}

The authors express their sincere gratitude to Assoc. Prof. Dr. Ali Ozer for his support in examination of SEM images and Yildirim Görler for his assist in CAD and CAM process. The study was funded by Scientific Research Projects Commission (CUBAP) of Cumhuriyet University, Sivas, Turkey (DIS-188).

\section{Monolitik Zirkonya Materyalinin Dentine Bağlanma Dayanımı Üzerine Farklı Tür Asit Yüzey Uygulamalarının Etkilerinin Araştırılması $\ddot{O} Z$}

Amaç: Bu çalışmanin amacl, dentin yüzeyine uygulanan sitrik, tartarik, fosforik ve borik asit uygulamasinin, monolitik zirkonyanın bağlanma dayanımına etkisini araştırmaktır. Gereç ve Yöntemler: Bu çallş̧mada, 100 adet insan dişi rastgele seçim yöntemiyle asit uygulama prosedürleri ve termal yorgunluk işlemlerine göre alt gruplara ayrlda $(n=10)$. Monolitik zirkonya restorasyonlar, CAD/CAM sistemi kullanilarak $3 \mathrm{~mm}$ kalınliğında ve $7 \mathrm{~mm}$ çapında üretildi. Dentin yüzeylerine asit uygulaması işleminin ardından, uygulanan asitlerin etkinliğini değerlendirmek üzere makaslama bağlantı dayanım testi uygulandl. Yüzey modifikasyonları taramalı elektron mikroskobu yardimiyla incelendi. Bulgular: Çalş̧ma gruplarl, termal yorgunluk uygulanmayan gruplar için (sitrik asit> tartarik asit> fosforik asit> borik asit> kontrol) ve termal yorgunluk uygulanan gruplar için (sitrik asit > tartarik asit) ve (fosforik asit $>$ borik asit> kontrol) en yüksek bağlanma değerine göre siralandl $(p<0,05)$. Termal yorgunluk uygulanan gruplarda; tartarik asit grubu ile fosforik asit grubu arasında bağlantı dayanım değerlerinde istatistiksel olarak anlamlilik saptanamadı ( $p>0,05)$. Sonuç: Termal yorgunluk içeren ve içermeyen her iki prosedürde; etkinlik sirasina göre sitrik, tartarik, fosforik ve borik asit uygulaması, monolitik zirkonya ile dentin arasindaki bağlantı dayanımını arttırmada daha başarılı olmuştur. Termal yorgunluk uygulaması tüm gruplarda bağlanma dayanımını azaltmıştır.

\section{REFERENCES}

1. Miyazaki T, Hotta Y, Kunii J, Kuriyama S, Tamaki Y. A review of dental CAD/CAM: current status and future perspectives from 20 years of experience. Dent
Mater J. 2009;28:44-56.

2. Denry I, Kelly JR. State of the art of zirconia for dental applications. Dent Mater. 2008;24:299-307.

3. Torricelli P, Verne E, Brovarone CV, Appendino P, Rustichelli F, Krajewski A, Ravaglioli A, Pierini G, Fini M, Giavaresi G, Giardino R. Biological glass coating on ceramic materials: in vitro evaluation using primary osteoblast cultures from healthy and osteopenic rat bone. Biomaterials 2001;22:2535-2543.

4. Stawarczyk B, Egli R, Roos M, Ozcan M, Hämmerle $\mathrm{CH}$. The impact of in vitro aging on the mechanical and optical properties of indirect veneering composite resins. J Prosthet Dent. 2011;106:386-398.

5. Swain MV. Unstable cracking (chipping) of veneering porcelain on all-ceramic dental crowns and fixed partial dentures. Acta Biomater. 2009;5:16681677.

6. Tuncel I, Turp I, Usumez A. Evaluation of translucency of monolithic zirconia and framework zirconia materials. J Adv Prosthodont. 2016;8:181-186.

7. Raadsheer MC, Van Eijden TMGJ, Van Ginkel FC, Prahl-Andersen B. Contribution of jaw muscle size and craniofacial morphology to human bite force magnitude. J Dent Res. 1999;78:31-42.

8. Lan TH, Liu PH, Chou MM, Lee HE. Fracture resistance of monolithic zirconia crowns with different occlusal thicknesses in implant prostheses. J Prosthet Dent. 2016;115:76-83.

9. Lan TH, Liu PH, Chou MM, Lee HE. Fracture resistance of monolithic zirconia crowns with different occlusal thicknesses in implant prostheses. J Prosthet Dent. 2016;115:76-83.

10. Nakamura K, Harada A, Inagaki R, Kanno $T$, Niwano Y, Milleding P, Örtengren U. Fracture resistance of monolithic zirconia molar crowns with reduced thickness. Acta Odontol Scand. 2015;73:602608.

11. Piconi C, Maccauro G. Zirconia as a ceramic biomaterial. Biomaterials. 1999;20:1-25.

12. Ural Ç, Kulunk T, Külünk $S$, Kurt M. The effect of laser treatment on bonding between zirconia ceramic surface and resin cement. Acta Odontol Scand. 2010;68:354-359.

13. Kosmac T, Oblak C, Jevnikar P, Funduk N, Marion $\mathrm{L}$. The effect of surface grinding and sandblasting on flexural strength and reliability of Y-TZP zirconia ceramic. Dent Mater. 1999;15:426-433.

14. Ersu B, Yuzugullu B, Ruya Yazici A, Canay S. 
Surface roughness and bond strengths of glassinfiltrated alumina-ceramics prepared using various surface treatments. J Dent. 2009;37:848-856.

15. Xible AA, de Jesus Tavarez RR, de Araujo Cdos R, Bonachela WC. Effect of silica coating and silanization on flexural and composite-resin bond strengths of zirconia posts: An in vitro study. J Prosthet Dent. 2006;95:224-229.

16. Ulgey M, Zan R, Hubbezoglu I, Gorler O, Uysalcan G, Cotur F. Effect of different laser types on bonding strength of CAD/CAM-customized zirconia post to root canal dentin: an experimental study. Lasers Med Sci. 2020 Feb 14.

17. Lussi, A. Dental erosion clinical diagnosis and case history taking. Eur J Oral Sci. 1996;104:191-198.

18. Garrett JS, Crigger M, Egelberg J. Effects of citric acid on diseased root surfaces. J Periodontal Res. 1978;13:155-163.

19. Pérez-Heredia M, Ferrer-Luque CM, GonzálezRodríguez MP, Martín-Peinado FJ, González-López S. Decalcifying effect of 15\% EDTA, $15 \%$ citric acid, 5\% phosphoric acid and $2.5 \%$ sodium hypochlorite on root canal dentine. Int Endod J. 2008;41:418-423.

20. Attin T, Meyer K, Hellwig E, Buchalla W, Lennon AM. Effect of mineral supplements to citric acid on enamel erosion. Arch Oral Biol. 2003;48:753-759.

21. Ravikumar J, Bhavana V, Thatimatla C, Gajjarapu S, Reddy SG, Reddy BR. The effect of four different irrigating solutions on the shear bond strength of endodontic sealer to dentin - An In-vitro study. J Int Oral Health. 2014;6:85-88.

22. Akisue E, Araki AT, Michelotto AL, Moura-Netto C, Gavini G. Effect of chemical and Er:YAG laser treatment on bond strength of root canal resin-based sealers. Lasers Med Sci. 2013;28:253-258.

23. Kameyama A, Kawada E, Takizawa M, Oda Y, Hirai $Y$. Influence of different acid conditioners on the tensile bond strength of 4-META/MMA-TBB resin to Er:YAG laser-irradiated bovine dentin. J Adhes Dent. 2000;2:297-304.

24. Demiryürek EO, Külünk S, Saraç D, Yüksel G, Bulucu B. Effect of different surface treatments on the push-out bond strength of fiber post to root canal dentin. Oral Surg Oral Med Oral Pathol Oral Radiol Endod. 2009;108:74-80.

25. Nicholson JW, Brookman PJ, Lacy OM, Wilson AD. Fourier transform infrared spectroscopic study of the role of tartaric acid in glass-ionomer dental cements. J
Dent Res. 1988;67:1451-1454.

26. Wiktorsson AM, Zimmerman M, Angmar-Månsson

B. Erosive tooth wear: prevalence and severity in Swedish winetasters. Eur J Oral Sci. 1997;105:544-550. 27. Fu B, Shen Q, Qian W, Zeng Y, Sun X, Hannig M. Interfacial interaction of tartaric acid with hydroxyapatite and enamel. J Mater Sci Mater Med. 2005;16:827-831.

28. Shimada Y, Yamaguchi S, Tagami J. Micro-shear bond strength of dual-cured resin cement to glass ceramics. Dent Mater. 2002;18:380-388.

29. Juloski J, Goracci C, Rengo C, Giovannetti A, Vichi A, Vulicevic ZR, Ferrari M. Enamel and dentin bond strength of new simplified adhesive materials with and without preliminary phosphoric acid-etching. Am J Dent. 2012;25:239-243.

30. Poggio C, Beltrami R, Colombo M, Chiesa M, Scribante A. Influence of dentin pretreatment on bond strength of universal adhesives. Acta Biomater Odontol Scand. 2017;3:30-35.

31. Alaghehmand $H$, Nezhad Nasrollah $F$, Nokhbatolfoghahaei H, Fekrazad R. An In Vitro Comparison of the Bond Strength of Composite to Superficial and Deep Dentin, Treated With Er:YAG Laser Irradiation or Acid-Etching. J Lasers Med Sci. 2016;7:167-171.

32. Davari A, Sadeghi M, Bakhshi H. Shear Bond Strength of an Etch-and-rinse Adhesive to Er:YAG Laser- and/or Phosphoric Acid-treated Dentin. J Dent Res Dent Clin Dent Prospects. 2013;7:67-73.

33. Azevedo M, Celeste C, Ana MV Cavaleiro. The acid-base titration of a very weak acid: boric acid. J Chem Educ. 2012;89:767-770.

34. Cangul S, Yildirim ZS, Bahsi E, Sagmak S, Satici O. Do ozone and boric acid affect microleakage in class $\mathrm{V}$ composite restorations?. Ozone-Sci Eng 2019;41:92101.

35. Ercan E, Colak H, Hamidi MM, Ibrahimov D, Gulal E. "Can Dentin Surfaces Be Bonded Safely With Ozone and Boric Acid?." Ozone-Sci Eng 2015;37:556-562.

36. Gale MS, Darvell BW. Thermal cycling procedures for laboratory testing of dental restorations. J Dent. 1999:27;89-99.

37.Earar K, Antoniac VI, Baciu S, Bran S, Onisor F, Milea $\mathrm{C}$, et al. Etching treatment effect on surface morphology of dental structures. Rev Chim 2017;68:2700-2703. 